Krzysztof Kazmiruk

\title{
PRZESTĘPSTWO PROWADZENIA POJAZDU W STANIE NIETRZEŹWOŚCI - WYBRANE ASPEKTY PRAWNOKARNE I KRYMINOLOGICZNE
}

1. Ustawą z dnia 14 kwietnia 2000 r., ${ }^{1}$ wprowadzono do kodeksu karnego nowy przepis, art. 178a, który penalizuje prowadzenie w stanie nietrzeźwości lub pod wpływem środka odurzającego pojazdu mechanicznego w ruchu lądowym, wodnym lub powietrznym $(\$ 1)$, oraz prowadzenie w stanie nietrzeźwości lub pod wpływem środka odurzającego innego pojazdu niż mechaniczny na drodze publicznej lub w strefie zamieszkania ( $(2)$. Przestępstwa te umieszczono w rozdziale XXI kk. - Przestępstwa przeciwko bezpieczeństwu w komunikacji.

Do czasu tych zmian zachowania takie były wykroczeniami. Ustawodawca uznał jednak, iż m.in. ze względu na poważne zagrożenie, jakie stwarza prowadzenie pojazdu w stanie nietrzeźwości lub pod wpływem środka odurzającego dla osoby prowadzącej pojazd oraz innych osób, jak również nagminność tego rodzaju zachowań, a także to, że bardzo często jazda w stanie nietrzeźwości kończy się tragicznymi skutkami w postaci wypadków powodujących śmierć i kalectwo ludzi, dotychczasowe środki nie były skuteczne. Podnoszono również, że sankcje zawarte w kodeksie wykroczeń są rażąco zaniżone w stosunku do szkodliwości społecznej czynów, których dotyczą ${ }^{2}$. Wprowadzając zmiany w prawie karnym, nie usunięto przepisów z prawa wykroczeń. Pozostawiono wykroczenie prowadzenia pojazdu mechanicznego w stanie po użyciu alkoholu lub podobnie działającego środka w ruchu lądowym, wodnym lub powietrznym oraz wykroczenie prowadzenia innego pojazdu w stanie po użyciu alkoholu lub podobnie działającego środka na drodze publicznej lub w strefie zamieszkania, skutkiem czego prowadzenie pojazdu ,po alkoholu" lub pod wpływem podobnie działającego środka jest teraz czynem przepołowionym.

2. Przedmiotem ochrony w przypadku czynów z art. 178a kk. jest bezpieczeństwo w komunikacji. Należy to odnieść do bezpieczeństwa w ruchu wodnym, lądo-

2 Por. Uzasadnienie projektu ustawy o zmianie ustawy - Kodeks karny, Sejm RP, III kadencja, druk nr 1019, s. 2. 
wym i powietrznym. Jednak największe zagrożenie występuje w ruchu lądowym, ze względu na łatwość dostępu do tego ruchu, a co za tym idzie większą ilość uczestników. Jako dalszy przedmiot ochrony można wskazać życie, zdrowie i mienie ${ }^{3}$.

Przestępstwa te mogą być popełnione tylko przez takiego sprawcę, który będąc w stanie nietrzeźwości lub po użyciu środka odurzającego prowadzi pojazd, a więc są to przestępstwa indywidualne właściwe. Wprawdzie zarówno prowadzenie pojazdu, jak i stan nietrzeźwości lub po użyciu środka odurzającego należą do znamion strony przedmiotowej jako określenie zachowania sprawcy, jednak znamiona te ograniczają również krąg podmiotów tych przestępstw. Nie można popełnić przestępstwa z art. 178a $§ 1$ lub 2 kk., jeżeli nie prowadzi się pojazdu i nie jest się w stanie nietrzeźwości lub pod wpływem środka odurzającego ${ }^{4}$. Część doktryny uważa jednak przestępstwa z art. 178a $\S 1$ i $2 \mathrm{kk}$. za przestępstwa powszechne ${ }^{5}$. Pojawia się także zdanie, że czyny te są przestępstwami indywidualnymi co do czynu ${ }^{6}$.

Przez prowadzenie pojazdu należy rozumieć każdą czynność, która bezpośrednio wpływa na ruch pojazdu ${ }^{7}$, w szczególności wprawianie go w ruch, kierowanie nim, nadawanie prędkości i hamowanie w sposób zgodny z konstrukcją pojaz$\mathrm{du}^{8}$. Takie stanowisko zajął Sąd Najwyższy, uznając, że „,do skazania na podstawie art. $28 \S 1$ ustawy o zwalczaniu alkoholizmu niezbędne jest ustalenie, że sprawca znajdujący się w stanie nietrzeźwości wprawił w ruch pojazd mechaniczny, którym wówczas zamierzał kierować. Samo zajęcie przez nietrzeźwego kierowcę miejsca za kierownicą i uruchomienie motoru z zamiarem prowadzenia pojazdu rozważać należy w płaszczyźnie usiłowania"9. Podobne zdanie do Sądu Najwyższego zaprezentował T. Cyprian ${ }^{10}$, powołując się na pogląd J. Sawickiego ${ }^{11}$. Uważa on, że ,prowadzenie" może dotyczyć jedynie pojazdu w ruchu, podjęcie zaś czynności zmierzających do rozpoczęcia tego ruchu jest usiłowaniem prowadzenia.

W przypadku pojazdów mechanicznych dodatkowym, niezbędnym elementem jest uruchomienie pojazdu, tj. uruchomienie mechanizmu wprawiającego po-

Odmiennie G. Bogdan, który uważa, iż błędem jest odnoszenie ochrony do mającego abstrakcyjny charakter pojęcia bezpieczeństwa w komunikacji. Jego zdaniem przedmiotem ochrony są życie, zdrowie i mienie, (w:) A. Zoll (red.), Kodeks karny. Część szczególna. Tom II. Komentarz do art. 117-277 kk, Warszawa 2008, s. 450. Kodeksu karnego. Komentarz, Warszawa 2000, s. 396; R.A. Stefański, (w:) M. Filar (red.), Kodeks karny. Komentarz, Warszawa 2008, s. 721.

5 Por. G. Bogdan, (w:) A. Zoll (red.), Kodeks karny. Część szczególna..., s. 450; J. Piórkowska-Flieger, (w:) T. Bojarski (red.), Kodeks karny. Komentarz, Warszawa 2009, s. 358.

$6 \quad$ M. Budyn-Kulik, (w:) M. Mozgawa (red.), Kodeks karny. Praktyczny komentarz, Kraków 2006, s. 344.

$7 \quad$ K. Buchała, Przestępstwa drogowe popełnione w stanie nietrzeźwości, Nowe Prawo 1960, nr 7-8, s. 992; S. Pawela, Kilka kwestii prawnych z zakresu nowej ustawy o zwalczaniu alkoholizmu, Nowe Prawo 1960, nr 12, s. 1642; G. Bogdan (w:) A. Zoll (red.), Kodeks karny. Część szczególna..., s. 451.

8 A. Marek, Kodeks karny. Komentarz, Warszawa 2006, s. 353-354.

9 Uchwała SN z dnia 8 grudnia 1960 r., VI KO 64/60, Państwo i Prawo 1961, nr 4-5, s. 845-846.

10 T. Cyprian, Alkohol a wypadki drogowe, Problemy Kryminalistyki 1961, nr 34, s. 770.

11 J. Sawicki, Karalne stany nietrzeźwości. Na marginesie ustawy antyalkoholowej z 1959 r., Państwo i Prawo 1960, nr 4-5, s. 651. 
jazd w ruch. Wyjątkiem jest holowany pojazd mechaniczny. Trafnie Sąd Najwyższy podkreślił, iż osoba prowadząca taki pojazd może być podmiotem przestępstwa określonego w art. 178a kk. ${ }^{12}$ Mimo iż pojazd prowadzony przez taką osobę nie porusza sie dzięki sile własnego mechanizmu napędzającego, lecz dzięki sile mechanizmu pojazdu holującego i sile bezwładności, posiada możliwość manewrowania oraz korzystania z urządzeń hamujących. Siedząc za kierownicą holowanego pojazdu mechanicznego, nadaje temu pojazdowi kierunek jazdy w sposób ograniczony długością połączenia holowniczego ${ }^{13}$.

Przyjmuje się, iż prowadzenie pojazdu nie oznacza pokonywania jakiegoś dłuższego odcinka drogi, a już uruchomienie pojazdu i podjęcie jazdy jest równoznaczne z jego prowadzeniem, bez względu na okres czasu prowadzenia pojazdu ${ }^{14}$.

Termin "prowadzi" - jak podniesiono w doktrynie - obejmuje swym zakresem nie tylko zachowanie będące czynnością kierującego, nadrzędną w ramach zespołu prowadzącego pojazd, lecz także czynności kilku uczestników takiego zespołu ${ }^{15}$. Sąd Najwyższy przyjąl, że dla oceny, czy dana osoba jest osobą prowadzącą pojazd, nie ma znaczenia czy podstawowe czynności prowadzenia pojazdu, jak nadanie kierunku, szybkości, hamowania itp. wykonuje jedna osoba, czy do każdej z tych czynności przewidziany jest osobny członek załogi. W sytuacji, gdy zachowanie kilku osób (co najmniej dwóch) polega na obsługiwaniu mechanizmów mających wpływ na jazdę, to wszystkie te osoby współuczestniczą w prowadzeniu pojazdu ${ }^{16}$.

Kodeks karny nie definiuje pojęcia pojazdu mechanicznego ani pojazdu innego rodzaju. Jedynie ustawa z 22 maja 2003 roku o ubezpieczeniach obowiązkowych, Ubezpieczeniowym Funduszu Gwarancyjnym i Polskim Biurze Ubezpieczycieli Komunikacyjnych ${ }^{17}$ zawiera definicję pojazdu mechanicznego, jednak nie może być ona stosowana do interpretacji tego pojęcia w kodeksie karnym ${ }^{18}$.

Pojazd mechaniczny został zdefiniowany przez Sąd Najwyższy m.in. w 1993 r. jako każdy pojazd drogowy lub szynowy, napędzany umieszczonym w nim silnikiem, jak również maszyna samobieżna i motorower. Nie są pojazdami mechanicznymi rowery zaopatrzone w silnik pomocniczy o pojemności nieprzekraczającej 50 $\mathrm{cm}^{3}$ pod warunkiem, że zachowują wszystkie normalne cechy charakterystyczne

Wyrok SN z dnia 18 marca 2003 r., (III KKN 390/01), OSNKW 2003, nr 5-6.

J. Izydorczyk, Prowadzenie holowanego pojazdu w stanie nietrzeźwości lub odurzenia. Uwagi na tle wyroku Sąu Najwyższego z dnia 18 marca 2003 roku, Paragraf na Drodze 2004, nr 1, s. 17.

E. Kostro, Alkohol. Komunikacja. Skutki prawne, Warszawa 1974, s. 60; K. Buchała, Glosa do wyroku SN z 3 lutego 1969 r., (V KRN 9/69), Państwo i Prawo 1970, nr 5, s. 832-833.

K. Buchała, Glosa do wyroku SN z 3 lutego 1969 r...., s. 832-833.

Wyrok SN z dnia 5 lutego 1987 r., V KRN 462/86, OSPiKA 1988, nr 1, poz. 12; R.A. Stefański, Glosa do wyroku SN z 5 lutego 1987 r., V KRN 462/87, Nowe Prawo 1989, nr 2-3, s. 239.

Dz.U. Nr 124, poz. 1152 ze zm.

Szerzej por. R.A. Stefański, Glosa do wyroku SN z dnia 25 października 2007 r., sygn. III KK 270/07, Prokuratura i Prawo 2008, nr 5, s. 166. 
budowy umożliwiające ich zwykłą eksploatację jako rowerów ${ }^{19}$. W 2007 roku Sąd Najwyższy ponownie wypowiedział się na ten temat i uznał, iż pojazdami mechanicznymi są pojazdy zaopatrzone w poruszający je silnik (pojazdy samochodowe, maszyny rolnicze, motocykle, lokomotywy kolejowe, samoloty, helikoptery, statki wodne i inne), jak również pojazdy szynowe zasilane z trakcji elektrycznej (tramwaje, trolejbusy $)^{20}$. Podobne definicje prezentowane są $\mathrm{w}$ doktrynie ${ }^{21}$.

Jeżeli chodzi o pojazdy inne niż mechaniczne, Sąd Najwyższy zaliczył do nich w szczególności zaprzęgi konne, rowery, a także statki żaglowe, szybowce. Ponadto potwierdził, iż nie są pojazdami mechanicznymi rowery zaopatrzone w silnik pomocniczy o pojemności skokowej nieprzekraczającej $50 \mathrm{~cm}^{3}$, które zachowują wszystkie normalne cechy charakterystyczne budowy, umożliwiające ich zwykłą eksploatację jako rowerów ${ }^{22}$.

O ile pojęcia ,pojazdu mechanicznego” i ,pojazdu innego rodzaju” czy pojęcie „prowadzenia pojazdu” nie budzą kontrowersji, to określenie dolnego pułapu stanu nietrzeźwości jako granicy odpowiedzialności za omawiane przestępstwa wywołuje w doktrynie kontrowersje. Stan nietrzeźwości zdefiniowany jest w art. $115 \S 16$ kk. jako stan, który zachodzi, gdy zawartość alkoholu we krwi przekracza 0,5\%o albo prowadzi do stężenia przekraczającego tę wartość lub wtedy, gdy zawartość alkoholu w $1 \mathrm{dm}^{3}$ wydychanego powietrza przekracza $0,25 \mathrm{mg}$ albo prowadzi do stężenia przekraczającego tę wartość. W uzasadnieniu do projektu ustawy wprowadzającej art. 178a do kodeksu karnego podnoszono, że to właśnie ten próg jest odpowiednią granicą dla usytuowania przestępstwa ${ }^{23}$. W literaturze przedmiotu podnoszono, iż określony w kodeksie karnym ,,próg nietrzeźwości” jest bardzo rygorystyczny ${ }^{24}$. Przeprowadzone badania wykazują, iż tylko $12 \%$ badanych osób ma wyraźne zakłócenia psychosomatyczne przy stężeniu alkoholu 0,5\% $0^{25}$. Prof. R.A. Stefański wskazał, że dopiero przy zawartości alkoholu pomiędzy 1,0\%o a 2,0\%o występują

19 Wyrok SN z dnia 4 lutego 1993 r.. III KRN 254/92, OSP 1993, nr 10, poz. 198.

20 Wyrok SN z dnia 25 października 2007 r., sygn. III KK 270/07, Prokuratura i Prawo 2008, nr 5, s. 165.

21 Por. G. Bogdan, (w:) A. Zoll (red.), Kodeks karny. Część szczególna..., s. 451; M. Budyn-Kulik, (w:) M. Mozgawa (red.), Kodeks karny..., s. 343; R.A. Stefański, (w:) A. Wąsek (red.) Kodeks karny. Część szczególna. Tom I. Komentarz do art. 117-221, Warszawa 2006, s. 607; O. Górniok, (w:) O. Górniok, S. Hoc, M. Kalitowski, S.M. Przyjemski, Z. Sienkiewicz, J. Szumski, L. Tyszkiewicz, A. Wąsek, Kodeks karny. Komentarz. Tom II. Art. 117-363, Gdańsk 2005, s. 166.

22 Wyrok SN z dnia 25 października 2007 r...., s. 165.

$23 \ldots$ „...jak dowiodły liczne badania - nawet małe ilości alkoholu (poniżej 0,5 promila) w organizmie człowieka powodują istotne zaburzenia percepcji i uwagi, upośledzenie koordynacji ruchów, osłabienie ostrości wzroku, zwężenie pola widzenia i akomodacji. Do tego dochodzi odhamowanie psychiczne, spotęgowanie reakcji popędowych, osłabienie samokrytycyzmu i poczucia odpowiedzialności, większa skłonność do ryzyka. Przy stężeniu przekraczającym 0,5 promila, od którego to progu kodeks karny w art. 115 § 16 pkt 1 przyjmuje istnienie stanu nietrzeźwości, wspomniane wyżej zaburzenia funkcji psychicznych i psychomotorycznych są regułą". Uzasadnienie projektu ustawy o zmianie ustawy - Kodeks karny, Sejm RP, III kadencja, druk nr 1019, s. 2.

24 Por. A. Marek, Prawo karne. Wyd. 3, Warszawa 2001, s. 481; B. Puchowski, Stan nietrzeźwości w nowej ustawie przeciwalkoholowej, Problemy Kryminalistyki 1960, nr 25, s. 316-318; T. Cyprian, Alkohol..., s. 765-766.

25 K. Buchała, P. Kardas, A. Zoll (red.), Kodeks karny, Tom II, Komentarz do art. 1-116 KK, Warszawa 1998, s. 404 . 
wyraźne zaburzenia psychomotoryczne i psychosensoryczne i zaproponował, aby przestępstwem był czyn polegający na prowadzeniu pojazdu przez osobę, w której organizmie zawartość alkoholu przekroczyłaby 1,5\%o, nazywając ten stan „stanem odurzenia alkoholowego"26.

Kodeks karny nie definiuje środka odurzającego. Według art. 4 pkt 26 ustawy z dnia 29 lipca 2005 r. o przeciwdziałaniu narkomaniii ${ }^{27}$, jest nim każda substancja pochodzenia naturalnego lub syntetycznego działająca na ośrodkowy układ nerwowy, określona w wykazie środków odurzających stanowiącym załącznik nr 1 do tej ustawy. W przeciwieństwie do stanu nietrzeźwości brakuje jednak miernika określającego zawartość środka odurzającego w organizmie powodującego zaburzenia czynności psychomotorycznych odpowiadających stanowi nietrzeźwości. Przeprowadzane badania często ograniczają się do stwierdzenia w organizmie obecności wyżej wymienionego środka, czasami jego rodzaju. Możliwe jest też oznaczenie ilościowe środka odurzającego znajdującego się w organizmie, lecz ze względu na brak stałego miernika może to mieć znaczenie pomocnicze dla określenia stopnia wpływu tego środka na zaburzenia świadomości ${ }^{28}$.

Przestępstwa zawarte w art. 178a kk. są przestępstwami formalnymi i polegają na prowadzeniu pojazdu w stanie nietrzeźwości lub pod wpływem środka odurzającego. Sam fakt prowadzenia pojazdu w takim stanie pociąga za sobą odpowiedzialność z wyżej wymienionego przepisu, nawet jeśli pojazd był prowadzony prawidłowo i kierujący nie sprowadził konkretnego niebezpieczeństwa ${ }^{29}$.

Są to przestępstwa umyślne. Sprawca ponosi odpowiedzialność na podstawie tego przepisu, gdy ma świadomość, że znajduje się w stanie nietrzeźwości lub pod wpływem środka odurzającego oraz gdy przewiduje, że alkohol nie został wydalony $\mathrm{z}$ organizmu i na to się godzi, a więc można je popełnić w zamiarze bezpośrednim i ewentualnym ${ }^{30}$.

Przestępstwo prowadzenia w stanie nietrzeźwości lub pod wpływem środka odurzającego pojazdu mechanicznego w ruchu lądowym, wodnym lub powietrznym zagrożone jest karą grzywny, karą ograniczenia wolności lub karą pozbawienia wolności do lat 2. Natomiast przestępstwo prowadzenia w stanie nietrzeźwości lub pod wpływem środka odurzającego innego pojazdu na drodze publicznej lub w strefie

26

27

28

29

30

Por. R.A. Stefański, Przestępstwa..., s. 396.

Dz.U. Nr 179 poz. 1485 ze zm.

R.A. Stefański, (w:) A. Wąsek (red.), Kodeks karny...s. 597-598.

Por. R.A. Stefański, (w:) A. Wąsek (red.), Kodeks karny..., s. 606; G. Bogdan, (w:) A. Zoll (red.), Kodeks karny. Część szczególna..., s. 451; R.A. Stefański, (w:) M. Filar (red.), Kodeks karny..., s. 729; A. Marek, Kodeks karny. Komentarz..., s. 354; M. Budyn-Kulik, (w:) M. Mozgawa (red.), Kodeks karny..., s. 343; J. Piórkowska-Flieger (w:) T. Bojarski (red.), Kodeks karny..., s. 358.

Por. R.A. Stefański, (w:) A. Wąsek (red.), Kodeks karny..., s. 606; G. Bogdan (w:), A. Zoll (red.), Kodeks karny. Część szczególna..., s. 452; R.A. Stefański, (w:) M. Filar (red.), Kodeks karny..., s. 729; A. Marek, Kodeks karny. Komentarz..., s. 354; M. Budyn-Kulik, (w:) M. Mozgawa (red.), Kodeks karny..., s. 344; J. Piórkowska-Flieger, (w:) T. Bojarski (red.), Kodeks karny..., s. 358. 
Przestępstwo prowadzenia pojazdu w stanie nietrzeźwości...

zamieszkania zagrożone jest karą grzywny, ograniczenia wolności lub pozbawienia wolności do roku.

W przypadku obu przestępstw możliwe jest również orzeczenie zakazu zajmowania określonego stanowiska, wykonywania określonego zawodu lub prowadzenia określonej działalności gospodarczej (art. 41 § 1 kk.), zakaz prowadzenia pojazdów (art. 42 kk.), świadczenie pieniężne, które nie może przekroczyć 60000 złotych (art. $49 \S 2$ kk.) oraz podanie wyroku do publicznej wiadomości (art. 50 kk.).

3. Jedną z konsekwencji wprowadzenia art. 178a do kodeksu karnego był znaczny wzrost zanotowanej przestępczości. Do roku 2001 zachowania te były wykroczeniami, więc nie były odnotowywane w statystykach przestępczości. Dopiero po roku 2001 można zobaczyć, jak duża jest skala tego zjawiska. Powołując się na statystyki Komendy Głównej Policji ${ }^{31}$, całkowita liczba przestępstw stwierdzonych w 2001 roku wyniosła 1390089 i statystycznie była wyższa niż w roku 2000 o 9,7\%. Faktycznie jednak ten wzrost spowodowany jest uznaniem 120162 przypadków kierowania pojazdem w stanie nietrzeźwym za przestępstwa. Przestępstw stwierdzonych bez art. 178 a $\S 1$ i 2 kk. policja zarejestrowała 1269927, co daje wzrost jedynie o $0,2 \%$ w stosunku do roku 2000.

Statystyki policyjne w kolejnych latach prezentują się następująco.

Tabela 1. Przestępstwa stwierdzone ${ }^{32}$

\begin{tabular}{|c|c|}
\hline \multicolumn{2}{|c|}{ Przestępstwa stwierdzone } \\
\hline Rok & Liczba przestępstw stwierdzonych \\
\hline 2001 & 1390089 \\
\hline 2002 & 1404229 \\
\hline 2003 & 1466643 \\
\hline 2004 & 1461217 \\
\hline 2005 & 1379962 \\
\hline 2006 & 1287918 \\
\hline 2007 & 1152993 \\
\hline 2008 & 1082057 \\
\hline
\end{tabular}

31 Raport Policji za rok 2001 dostępny na stronie http://www.policja.pl/portal/pol/6/6/Raport_2001.html; http://www. policja.pl/portal/pol/19/365/Prowadzenie_pojazdu_w_stanie_nietrzezwosci_art_178a.html

32 Dane Komendy Głównej Policji, http://www.policja.pl/portal/pol/3/1/Przestepstwa_stwierdzone_podejrzani_wykrywalnosc_ogolem_w_latach_19902007.html 
Krzysztof Kazmiruk

Tabela 2. Stwierdzone przestępstwo prowadzenia pojazdu w stanie nietrzeźwości lub pod wpływem środka odurzającego (art. 178a kk.) ${ }^{33}$

\begin{tabular}{|c|c|c|c|}
\hline \multicolumn{4}{|c|}{$\begin{array}{c}\text { Stwierdzone przestępstwo prowadzenia pojazdu w stanie nietrzeźwości } \\
\text { lub pod wpływem środka odurzającego (art. 178a kk.) }\end{array}$} \\
\hline Rok & $\S 1$ & $\S 2$ & Razem \\
\hline 2001 & 68672 & 51490 & 120162 \\
\hline 2002 & 78363 & 66091 & 144445 \\
\hline 2003 & 75301 & 75662 & 150963 \\
\hline 2004 & 78048 & 80555 & 158603 \\
\hline 2005 & 85544 & 93124 & 178668 \\
\hline 2006 & 84120 & 96926 & 181046 \\
\hline 2007 & 79210 & 71233 & 150443 \\
\hline 2008 & 83944 & 66202 & 150146 \\
\hline
\end{tabular}

Jeżeli chodzi o statystykę osób prawomocnie skazanych wyrokiem sądu, obrazuje ją Tabela 3 .

Jak pokazują statystyki, liczba stwierdzonych przestępstw z art. 178a kk. utrzymuje się na stałym poziomie, ponad stu tysięcy rocznie. Od 2007 roku liczba ta jest niższa niż w latach ubiegłych, co można tłumaczyć spadkiem liczby przestępstw stwierdzonych. Jednak procentowy udział przestępstw z art. 178a kk. w ogólnej liczbie przestępstw stwierdzonych kształtuje się w granicach kilkunastu procent. W 2001 roku było to $8,6 \%$, w $2003-10,3 \%$, w $2003-10,3 \%$, w $2004-10,9 \%$, w 2005 - 12,9\%, w 2006 - 14,1\%, w 2007 - 13,0\%, w 2008 - 13,9\% 34. Dzięki tym danym można zobaczyć, że udział ten w ostatnich latach jest najwyższy od 2001 roku. Zestawienie daje obraz, jak duża jest skala tego zjawiska. Jest to problem budzący wiele kontrowersji i często poruszany w mediach. 
Przestępstwo prowadzenia pojazdu w stanie nietrzeźwości...

Tabela 3. Prawomocne skazania osób dorosłych za przestępstwo prowadzenia pojazdu w stanie nietrzeźwości lub pod wpływem środka odurzającego (art. 178a kk.) ${ }^{35}$

\begin{tabular}{|c|c|c|c|}
\hline \multicolumn{4}{|c|}{$\begin{array}{c}\text { Prawomocne skazania osób dorosłych za przestępstwo prowadzenia pojazdu } \\
\text { w stanie nietrzeźwości lub pod wpływem środka odurzającego(art. 178a kk.) }\end{array}$} \\
\hline Rok & $\S 1$ & $\S 2$ & Razem \\
\hline 2001 & 41905 & 33718 & 75623 \\
\hline 2002 & 66362 & 52256 & 114618 \\
\hline 2003 & 64860 & 65050 & 129910 \\
\hline 2004 & 71162 & 74456 & 145618 \\
\hline 2005 & 73175 & 79985 & 153160 \\
\hline 2006 & - & - & 145117 \\
\hline 2007 & - & - & 138811 \\
\hline
\end{tabular}

4. W ostatnich tygodniach media zostały zdominowane kwestią odpowiedzialności tzw. „pijanych rowerzystów”. Wiązało się to z orzeczeniem Trybunału Konstytucyjnego z dnia 7 kwietniu 2009 r. $^{36}$ w kwestii zgodności z Konstytucją RP art. 178a $\S 2$ kodeksu karnego. Trybunał orzekł w odpowiedzi na połączone pytania prawne Sądu Rejonowego we Wschowie, II Wydział Karny, dotyczące odpowiedzialności karnej nietrzeźwego rowerzysty. Zdaniem sądu pytającego art. 178a § 2 kk. naruszał zasadę równości obywateli wobec prawa (art. 32 ust 1 Konstytucji RP), a przez to naruszał również zasadę sprawiedliwości społecznej (art. 2 Konstytucji RP) i zasadę proporcjonalności (art. 31 ust 3 Konstytucji RP). Według sądu pytającego kwestionowany przepis nierówno traktował bowiem takich samych rodzajowo, poruszających się za pomocną mięśni, uczestników ruchu drogowego, tj. rowerzystów i pieszych. Zachowania nietrzeźwego pieszego karane są bowiem na podstawie art. $86 \S 2 \mathrm{kw}$. (kto nie zachowując należytej ostrożności, powoduje zagrożenie bezpieczeństwa w ruchu drogowym znajdując się w stanie po użyciu alkoholu), co zagrożone jest karą aresztu, ograniczenia wolności albo grzywny, natomiast nietrzeźwy rowerzysta odpowiada na podstawie art. 178a § 2 kk. za występek. Kodeks karny przewiduje za ten czyn grzywnę, karę ograniczenia wolności albo karę pozbawienia wolności do roku.

35 Lata 2001-2005 - Dane Ministerstwa Sprawiedliwości, http://www.ms.gov.pl/statystyki/2005_prawomocne.pdf;
lata 2006-2007 - Rocznik Statystyczny Rzeczypospolitej Polskiej, Warszawa 2009, s. 178. 
Trybunał Konstytucyjny orzekł, że art. 178a § 2 kodeksu karnego nie narusza zasady równości wyrażonej w art. 32 Konstytucji $\mathrm{RP}^{37}$.

Uzasadniając swoje stanowisko, Trybunał przyznał, iż podobieństwo między pieszym a rowerzystą jako uczestnikami ruchu polega na tym, że oba te podmioty poruszają się za pomocą własnych mięśni, a nie przy użyciu pojazdu napędzanego mechanicznie. Jak jednak słusznie zauważono, istnieje zasadnicza różnica między tymi podmiotami, polegająca na tym, że pieszy jest uczestnikiem ruchu poruszającym się samodzielnie, tj. bez użycia jakiegokolwiek pojazdu w znaczeniu przyjętym przez doktrynę prawa karnego, podczas gdy rowerzysta jest osobą kierującą pojazdem innym niż mechaniczny. Słusznie podniesiono, że w przypadku kierowcy pojazdu mechanicznego, nietrzeźwy rowerzysta jest większym zagrożeniem niż nietrzeźwy pieszy przede wszystkim dlatego, że jego ruchy są nieprzewidywalne, a przy większej prędkości jest w stanie szybciej niż nietrzeźwy pieszy zmienić kierunek ruchu i spowodować kolizję z kierowcą pojazdu mechanicznego. Również w stosunku do pieszego, rowerzysta będący w stanie nietrzeźwości stanowi większe zagrożenie niż pieszy, ze względu na większą masę. Za niezasadny uznano argument sądu pytającego, iż nietrzeźwy rowerzysta porusza się z prędkością porównywalną do prędkości, z jaką porusza się pieszy ${ }^{38}$. Wydaje się, iż w przypadku, gdy nietrzeźwy rowerzysta nie może osiągnąć większych prędkości niż przeciętny pieszy, może mieć również trudności z samym kierowaniem takim pojazdem. W tym stanie rzeczy pozostaje takiej osobie tylko "ciągnąć" lub ,pchać” rower, co zgodnie z ustawą Prawo o ruchu drogowym będzie skutkowało traktowaniem takiej osoby jak pieszego.

W uzasadnieniu zwrócono również uwagę na to, iż status obu rodzajów podmiotów - pieszego i rowerzysty - jest inny także na gruncie ustawy z 20 czerwca 1997 r. - Prawo o ruchu drogowym ${ }^{39}$. Art. 2 pkt 18 wymienionej ustawy mówi, że pieszym jest osoba znajdująca się poza pojazdem na drodze i niewykonująca na niej robót lub czynności przewidzianych odrębnymi przepisami. Za pieszego uważa się także osobę prowadzącą, ciągnącą lub pchającą rower, motorower, motocykl, wózek dziecięcy, podręczny lub inwalidzki, osobę poruszającą się w wózku inwalidzkim, a także osobę w wieku do 10 lat kierującą rowerem pod opieką osoby dorosłej. W punkcie 47 tego artykułu zdefiniowano rower jako pojazd jednośladowy lub wielośladowy poruszany siłą mięśni osoby jadącej tym pojazdem. Również w doktrynie

37 Wypowiadając się w kwestii naruszenie zasad sprawiedliwości społecznej i proporcjonalności, Trybunał stwierdził nieadekwatność art. 31 ust 3 Konstytucji RP i art. 2 Konstytucji RP jako wzorca kontroli, http://www.trybunal. gov.pl/Rozprawy/2009/P_07_08.htm 
rower został uznany za pojazd innego rodzaju niż mechaniczny, o jakim jest mowa w art. $178 \mathrm{a} \S 2 \mathrm{kk}^{40}$

5. Zaskakiwać mogą doniesienia prasowe i wypowiedzi przedstawicieli resortu sprawiedliwości po ogłoszeniu orzeczenia Trybunału Konstytucyjnego ${ }^{41}$. Na aprobatę zasługują propozycje Ministerstwa Sprawiedliwości poprawy funkcjonowania kary ograniczenia wolności i zapowiedź „sugestii” prokuratorom, aby domagali się kary pozbawienia wolności jedynie w stosunku do „uporczywych recydywistów”. Wątpliwości budzić może wypowiedź dotycząca stosowania przepadku roweru w stosunku do tej kategorii sprawców jako środka mającego „błyskawicznie ograniczyć proceder jazdy po alkoholu”. Co prawda nie wiadomo jeszcze, na jakiej podstawie miałby być orzekany ten środek karny.

6. Warto w tym miejscu przypomnieć, iż w 2006 roku ówczesny Prokurator Generalny skierował do prokuratorów wytyczne z dnia 20 czerwca 2006 r., w których m.in. polecił bezwzględne wnioskowanie o przepadek samochodu wobec sprawców uprzednio skazanych za występek z art. 178a $§ 1$ kk. Art. 44 kk. wyróżnia trzy rodzaje przedmiotów, które mogą, a w niektórych przypadkach muszą ulec przepadkowi. W § 1 wspomnianego artykułu mowa jest o obligatoryjnym przepadku przedmiotów pochodzących bezpośrednio z przestępstwa. $§ 2$ stanowi o fakultatywnym, a w wypadkach wskazanych w ustawie obligatoryjnym przepadku przedmiotów, które służyły lub były przeznaczone do popełnienia przestępstwa, natomiast w $§ 6$ uregulowano fakultatywny, a w wypadkach wskazanych w ustawie obligatoryjny przepadek przedmiotów objętych zakazem wytwarzania, posiadania, obrotu, przesyłania, przenoszenia lub przewozu (gdy sprawcę skazano za przestępstwo polegające na naruszeniu tych zakazów). Wskazany przepadek orzekano na podstawie $\S 2$ art. $44 \mathrm{kk}$. Ze względu na występujące w orzecznictwie sądów powszechnych rozbieżności ${ }^{42}$ Prokurator Generalny skierował również wniosek o podjęcie przez Sąd Najwyższy uchwały mającej na celu rozstrzygnięcie wątpliwości sądów i wyjaśnienie, czy możliwe jest orzeczenie na podstawie art. $44 \S 2 \mathrm{kk}$. przepadku pojazdu mechanicznego prowadzonego przez sprawcę przestępstwa określonego w art. 178a $\S 1$ $\mathrm{kk}$.

Sąd Najwyższy w uchwale ${ }^{43}$ z 30 października 2008 roku uznał stosowanie takiego przepadku za niemożliwe, gdyż zdaniem sądu zakres art. $44 \S 2$ nie obejmu-

40 Por. O. Górniok, (w:) O. Górniok, S. Hoc, M. Kalitowski, S.M. Przyjemski, Z. Sienkiewicz, J. Szumski, L. Tyszkiewicz, A. Wąsek, Kodeks karny..., s. 166; J. Piórkowska-Flieger, (w:) T. Bojarski (red.), Kodeks karny..., s. 358; A. Marek, Kodeks karny. Komentarz..., s. 112-113; R.A. Stefański, Przestępstwa..., s. 407

41 Wywiad z Krzysztofem Kwiatkowskim, sekretarzem stanu w Ministerstwie Sprawiedliwości, Gazeta Wyborcza z 11.04.2009 r., http://wyborcza.pl/1,76842,6490628,Pijanym_rowerzystom_zabiora_rowery_.html

42 Rozbieżności dotyczyły wykładni pojęcia „narzędzie przestępstwa” w rozumieniu art. $44 \S 2$ kk. w odniesieniu do pojazdów mechanicznych w sprawach o prowadzenie pojazdu w stanie nietrzeźwości lub pod wpływem środka odurzającego. Szerzej por. A. Herzog, Pojazd mechaniczny jako narzędzie przestępstwa z art. 178a § 1 kk., Paragraf na Drodze 2008, nr 9, s. 9-13. Uchwała SN z dnia 30 października 2008, sygn. akt I KZP 20/08, OSNKW 2008, nr 11, poz. 88. 
je przedmiotów czynności wykonawczej, jakim jest pojazd mechaniczny z art. 178a $\S 1$.

Uzasadniając, Sąd Najwyższy podniósł, iż prowadzenie pojazdu mechanicznego w ruchu lądowym, wodnym lub powietrznym przez sprawcę będącego w stanie nietrzeźwości lub pod wpływem środka odurzającego jest czynnością sprawczą. Pojazd ten uznano za materialny obiekt, którym sprawca dokonuje czynu zabronionego czy nawet na którym następuje dokonanie ${ }^{44}$, a jego użycie przez prowadzenie wypełnia znamiona strony przedmiotowej ${ }^{45}$. Dlatego też uznano pojazd mechaniczny za przedmiot czynności wykonawczej (przedmiot wykonawczy).

W uzasadnieniu słusznie zwrócono również uwagę na to, iż pojęcie przedmiotu czynności wykonawczej przestępstwa jest całkowicie różne od pojęcia przedmiotu, który służy do popełnienia przestępstwa i zasygnalizowano wykluczanie się tych pojęćt ${ }^{46}$. Uznano, iż pojazd mechaniczny prowadzony przez sprawcę jako przedmiot czynności wykonawczej nie służy, w rozumieniu art. $44 \S 2 \mathrm{kk}$., popełnieniu przestępstwa, lecz jako składowa opisu czynności sprawczej współokreśla samą istotę typu przestępstwa ${ }^{47}$.

Ilustrując relację przedmiotu wykonawczego do przedmiotu służącego do popełnienia przestępstwa w innych typach przestępstw, Sąd Najwyższy podaje przykład cudzej rzeczy ruchomej, która nie jest przedmiotem służącym do popełnienia przestępstwa kradzieży (art. $278 \S 1 \mathrm{kk}$.) oraz dokumentu niebędącego przedmiotem służącym do popełnienia przestępstwa fałszerstwa dokumentu (art. $270 \S 1 \mathrm{kk}$.), pomimo iż każdy z tych przedmiotów zostaje użyty przy popełnieniu przestępstwa w tym sensie, że bez skierowania do nich czynności sprawczej dokonanie nie byłoby możliwe ${ }^{48}$.

Trafnie Sąd Najwyższy zwraca uwagę, że zdarza się, aby przedmioty służące popełnieniu przestępstwa w niektórych typach przestępstw należały do znamion strony przedmiotowej (np. $280 \S 2 \mathrm{kk}$. - broń palna lub nóż), ale wtedy przedmioty takie nie są przedmiotami czynności wykonawczych. Służą one dokonaniu w szczególny sposób czynności sprawczych, co - zdaniem Sądu - zwiększa szkodliwość społeczną czynu w stopniu, który uzasadnia odrębną typizację. Nie tracą one jednak funkcji przedmiotów służących do popełnienia przestępstwa ${ }^{49}$.

SN powołał się na I. Andrejew, Ustawowe znamiona czynu. Typizacja i kwalifikacja przestępstw, Warszawa 1978, s. 186 i nast.; J. Waszczyński (red.), Prawo karne w zarysie, Łódź 1979, s.101-102.

Podobnie A. Wasek, Narzędzia przestępstwa, Annales UMCS 1968 vol. XV, s. 274-275.

Podobnie K. Potulski, M. Siwek, Przepadek w polskim prawie karnym, Kraków 2004, s. 142.

Por. uzasadnienie uchwały SN z dnia 30 października 2008, sygn. akt I KZP 20/08, s. 9; A. Wassek, Narzędzia..., s. $274-275$.

48 Por. uzasadnienie uchwały SN z dnia 30 października 2008 r...., s. 11.

49 Ibidem, s. 11 
Podobne stanowisko zajął R.A. Stefański w glosie ${ }^{50}$ do omawianej uchwały, jednak odrzucił proponowaną przez Sąd Najwyższy argumentację. Zdaniem tego autora, pojazd mechaniczny wymieniony $\mathrm{w}$ art. 178a $\S 1 \mathrm{kk}$. nie podlega przepadkowi z art. $44 \S 2 \mathrm{kk}$. nie dlatego, że jest przedmiotem wykonawczym, lecz dlatego, że nie może być zaliczony do żadnej z grup przedmiotów podlegających przepadkowi - nie tylko z art. $44 \S 2$ kk. Swoje stanowisko R.A. Stefański argumentuje tym, iż pojazd mechaniczny, który stanowi znamię przestępstwa i bez którego znamiona przestępstwa byłyby niekompletne, nie może być uznany za przedmiot służący do popełnienia przestępstwa. Mógłby być uznany za taki tylko w przypadku, gdy mogło dojść do realizacji znamion tego przestępstwa bez jego używania, co - ze względu na konstrukcję znamion w art. 178a § 1 kk. - jest niemożliwe ${ }^{51}$.

Opierając się na powyższych rozważaniach, orzekanie przepadku pojazdów innego rodzaju niż mechaniczne na podstawie art. 44 § 2 kk. również wydaje się niemożliwe.

7. Inną drogą która dałaby możliwość orzekania tego środka karnego wobec „pijanych” rowerzystów jest wprowadzenie nowego przepisu lub zmiana już istniejącego. W przeszłości kilkukrotnie proponowano znowelizowanie kodeksu karnego tak, aby możliwe było orzekanie przepadku pojazdów za przestępstwa z art. 178a. Już podczas prac nad zmianami w kodeksie w 1999 roku pojawił się projekt ${ }^{52}$, który przewidywał obligatoryjny przepadek pojazdu m.in. za przestępstwo prowadzenia pojazdu w stanie nietrzeźwości lub pod wpływem środka odurzającego (art. $178^{1} \S 1$ kk. - obecnie 178a §1 kk.) $)^{53}$. Również, wniesiony do Sejmu RP 18 maja 2007 r. rządowy projekt nowelizacji kodeksu karnego i niektórych innych ustaw (druk sejmowy 1756) proponował zmianę treści $\S 2$ art. 178a oraz dodanie $\S 3$ do omawianego przepisu. Przepadek miałby być orzekany obligatoryjnie za występek z $§ 1$ art. 178a kk., chyba że zaistniałyby szczególne względy przemawiające przeciwko orzeczeniu przepadku (wtedy sąd miałby orzekać nawiązkę na rzecz Funduszu Pomocy Ofiarom Przestępstw). Potrzebę takiej zmiany uzasadniano potrzebą zaostrzenia represji karnej względem sprawców przestępstw komunikacyjnych popełnionych w stanie nietrzeźwości lub pod wpływem środka odurzającego, a przede wszystkim postrzegano w tej propozycji narzędzie odstraszające potencjalnych sprawców ${ }^{54}$.

\footnotetext{
50 Glosa do uchwały składu 7 sędziów SN z dnia 30 października 2008 r., sygn. I KZP 20/08, Prokuratura i Prawo 2009, nr 3, s. 141-147; inaczej A. Herzog, Pojazd mechaniczny..., s. 16.

Glosa do uchwały składu 7 sędziów SN z dnia 30.10 .2008 r., s. 143.

Druk sejmowy nr 1019.

Projekt ten spotkał się z krytyką doktryny, por. L.K. Paprzycki, Opinia dotycząca ustawy o zmianie ustawy - Kodeks karny (druk sejmowy nr 1019), maszynopis powielony, s. 2-4; R.A. Stefański, Opinia o projekcie ustawy o zmianie ustawy - Kodeks karny (druk nr 1019), s. 2, [za:] R.A. Stefański, Glosa do uchwały składu 7 sędziów SN z dnia 30 października 2008 r., s. 145.

54 Por. uzasadnienie projektu ustawy z 17 maja 2007 r. o zmianie ustawy - Kodeks karny oraz niektórych innych
} 
Co prawda obie propozycje odnosiły się do $§ 1$ art. 178a kk., jednak w świetle słów przedstawiciela resortu sprawiedliwości nie można wykluczyć przyszłych prób wprowadzenia do kodeksu karnego zmian umożliwiających orzekanie przepadku pojazdu innego niż mechaniczny w przypadku popełnienia występku $\mathrm{z}$ art. $178 \mathrm{a} \S 2 \mathrm{kk}$.

Takie zabiegi należałoby ocenić negatywnie. Wątpliwe jest osiągnięcie skutku, jakim ma być zmniejszenie liczby sprawców przestępstwa $\mathrm{z}$ art. 178a $§ 2 \mathrm{kk}$. W latach 2006-2008, kiedy orzekano przepadek pojazdów mechanicznych za czyn z art. 178a $§ 1$ kk., procentowy udział przestępstw z art. 178a kk. w ogólnej liczbie przestępstw stwierdzonych wynosił odpowiednio 14,1\%, 13,0\%, 13,9\%, czyli najwięcej od 2001 roku. Można zaryzykować stwierdzenie, że orzekanie tego środka karnego w stosunku do nietrzeźwych rowerzystów, których pojazdy mają znacznie niższą wartość niż np. samochody, będzie jeszcze mniej efektywne niż w przypadku kierowców, tzn. nie spowoduje spadku przestępczości. Warto również zauważyć, iż orzeczenie środka karnego z art. $44 \S 2 \mathrm{kk}$. często godziłoby nie tylko w sprawcę przestępstwa, ale również w jego rodzinę. Czasami odebranie wartego kilkaset złotych roweru może poważnie uszczuplić rodzinny budżet. Jak już wspomniano, przestępstwa $\mathrm{z}$ art. 178a kk. są przestępstwami formalnymi, z abstrakcyjnego narażenia na niebezpieczeństwo, dlatego słusznym będzie stwierdzenie, iż orzekanie przepadku byłoby niewspółmierne do wagi popełnionego czynu.

8. Równie represyjne propozycje pojawiają się $\mathrm{w}$ poselskim projekcie ustawy o zmianie ustawy - Kodeks karny z 28 kwietnia 2009 roku$^{55}$, w którym proponuje się zmianę $\S 3$ i $§ 4$ art. 42 kk. oraz dodanie $\S 3$ do art. 178a kk. Projekt zakłada wprowadzenie obowiązku obligatoryjnego orzekania zakazu prowadzenia pojazdów mechanicznych na zawsze, jeżeli sprawca w czasie popełnienia przestępstwa określonego w art. 173 lub 174 kk., którego następstwem jest śmierć innej osoby lub ciężki uszczerbek na jej zdrowiu, albo w czasie popełnienia przestępstwa określonego w art. 177 § 2 lub w art. 355 § kk. był w stanie nietrzeźwości, pod wpływem środka odurzającego lub zbiegł z miejsca zdarzenia. Proponowane jest także orzekanie tego środka karnego na zawsze w razie ponownego skazania osoby prowadzącej pojazd mechaniczny za przestępstwo określone w art. 178a $§ 1 \mathrm{kk}$. Natomiast projektowany $\S 3$ art. 178a kk. mówi, że jeśli sprawca czynu określonego w $§ 1$ był uprzednio prawomocnie skazany za prowadzenie pojazdu mechanicznego w stanie nietrzeźwości, podlega karze pozbawienia wolności od lat 3 do 5.

Autorzy projektu uzasadniają zmiany sytuacją na polskich drogach. Powołując się na dane Policji (w 2008 roku nietrzeźwi kierujący pojazdami spowodowali 3529 wypadków, co w odniesieniu do ogólnej liczby wypadków spowodowanych przez 
kierujących pojazdami stanowi 9,2\%), wyrażają opinię, że wprowadzone ostatnio zaostrzenia przepisów w przedmiotowej materii nie przyniosły oczekiwanych skutków z uwagi na sporadyczność ich stosowania ${ }^{56}$.

Do proponowanych zmian należy odnieść się sceptycznie. Obligatoryjne orzekanie zakazu prowadzenia pojazdów mechanicznych na zawsze w razie ponownego skazania za formalne przestępstwo prowadzenia pojazdu w stanie nietrzeźwości lub pod wpływem środka odurzającego wydaje się być nadmiernie surowe. Już przy okazji wprowadzenia do kodeksu karnego obecnie obowiązujących $\S 3$ i $\S 4$ art. 42 kk. zauważono, iż tak rygorystyczne regulacje są wyrazem przesadnej wiary w skuteczność surowej represji karnej ${ }^{57}$. Ta propozycja nie znalazła również uznania wśród praktyków. Krajowa Rada Sądownictwa w opinii z dnia 4 czerwca 2009 r. zauważyła, że obligatoryjne orzekanie środka karnego określonego w art. 42 § kk. i 42 § kk. jest sprzeczne z zasadą indywidualizacji kary i ogranicza w sposób bezpodstawny swobodę sędziowskiego uznania w tym zakresie ${ }^{58}$.

Odnosząc się do propozycji dodania $§ 3$ do art. 178a kk., nie sposób nie zauważyć, że w przypadku swoistego rodzaju „recydywy” dolny wymiar kary wynosiłby 3 lata, czyli czyn taki stanowiłby zbrodnię. Wątpliwe jest, czy owa zmiana jest zasadna. Należy pamiętać, iż prowadzenie pojazdu mechanicznego w stanie nietrzeźwości lub pod wpływem środka odurzającego jest przestępstwem formalnym, z abstrakcyjnego narażenia i aby ponosić odpowiedzialność karną, nie jest konieczne wywołanie skutku. Tak surowe zagrożenie wydaje się być niewspółmierne do wagi czynu, zwłaszcza jeżeli weźmie się pod uwagę obecnie obowiązujące uregulowania dotyczące powrotu do przestępstwa, które w przypadku ponownego skazania sprawcy występku z art. 178a $\S 1 \mathrm{kk}$. na karę pozbawienia wolności pozwalają sądowi wymierzyć karę do górnej granicy ustawowego zagrożenia zwiększonego o połowę (będą to 3 lata - czyli dolna granica ustawowego zagrożenia w projekcie). Podobne zdanie można znaleźć w opinii Państwowej Agencji Rozwiązywania Problemów Alkoholowych ${ }^{59}$. Również Krajowa Rada Sądownictwa negatywnie zaopiniowała ten projekt, podnosząc, iż obecnie obowiązująca regulacja w sposób wystarczający zapewnia ochronę w zakresie przestępstw przeciwko bezpieczeństwu w komunikacji, związanych z prowadzeniem pojazdu w stanie nietrzeźwości lub pod wpływem środka odurzającego ${ }^{60}$.

Wydaje się, że próba poprawy sytuacji na polskich drogach przez zwiększenie represji karnej nie jest dobrym rozwiązaniem. Przeciwko takiemu zaostrzeniu, w szczególności jeżeli chodzi o podniesienie progów sankcji w proponowanym $\S 3$

\footnotetext{
56 Por. uzasadnienie projektu ustawy z 28 kwietnia 2009 r., Druk sejmowy nr 2115, s. 2-3.

57 A. Marek, Prawo karne..., s. 281.

58 Opinia w przedmiocie projektu ustawy o zmianie ustawy - Kodeks karny, Druk sejmowy nr 2115.

59 Druk sejmowy nr 2115.

60 Ibidem.
} 
art. 178a kk., przemawia również sytuacja więziennictwa związana z przeludnieniem zakładów karnych ${ }^{61}$. Poprawy tej można upatrywać w zmianie świadomości społecznej obywateli. Większa ilość akcji, takich jak „Piłeś, nie jedź!”, która objęła zasięgiem cały kraj i polegała na pojawianiu się w środkach masowego przekazu reklam, spotów i informacji o tym, jak szkodliwe jest prowadzenie pojazdu pod wpływem alkoholu, może spowodować zmianę postrzegania przestępstwa prowadzenia pojazdu w stanie nietrzeźwości i ograniczyć to zjawisko ${ }^{62}$.

61 Szerzej M. Melezini, Czy zaostrzyć represję karna? (w:) J. Jakubowska-Hara, C. Nowak, J. Skupiński (red.), Reforma prawa karnego. Propozycje i komentarze. Księga Pamiątkowa Profesor Barbary Kunickiej-Michalskiej, Warszawa 2008, s. 157-158.

62 Podobne zdanie wyraziła M. Melezini w dyskusji podczas I Forum Naukowego „Podlasie - Warmia i Mazury” nt. „Aktualne problemy prawa karnego i kryminologii” - Ryn, 20-22 maja 2009 r., materiał z dyskusji niepublikowany. 


\section{SUMMARY}

Until 2001 driving under influence was only a petty offence but an Act of April 14, 2000, introduced art. 178a, which penalizes driving a vehicle in a state of inebriation, into Polish Penal Code. One of the consequences was a dramatic increase in number of traffic offences and as a result, increased number of crime in general. Statistics show that this offence is very common and there are many problems connected with it.

In the paper the author analyses this offence, as well as discusses two highly disputable matters, both of them involve drunk cyclists. First is the sentence of the Constitutional Tribunal of April 7, 2009, which ruled that art. 178a $\S 2$ (penalizes drunk cycling) of Penal Code is not contradictory to Polish Constitution. Second one is whether a bicycle ridden by a drunk cyclist who committed an offence under art. 178a $\S 2$ of Penal Code should be treated as an offence tool, and whether it is acceptable for a court to impose forfeiture of such a vehicle.

In the last part of the paper the author comments on changes in art. 178a proposed by deputies. 